\title{
Screening for hepatocellular carcinoma: summary of current guidelines up to 2018
}

\author{
Nevin Yilmaz ${ }^{1,2}$, Ugur Eser Yilmaz ${ }^{3}$, Kaya Suer $^{4}$, Vedat Goral $^{5}$, Nedim Cakir $^{4}$ \\ 'Gastroenterology Section, Research and Trainee Hospital, Mugla Sitki Kocman University, Mugla 48000, Turkey. \\ ${ }^{2}$ Gastroenterology/Hepatology Department, Near East University School of Medicine, Nicosia, Mersın 10, Northern Cyprus. \\ ${ }^{3}$ Koc University School of Medicine, Istanbul 34010, Turkey. \\ ${ }^{4}$ Department of Infectious Diseases and Clinical Microbiology, Near East University School of Medicine,Nicosia, Mersın 10, Northern Cyprus. \\ ${ }^{5}$ Department of Gastroenterology, Medipol University School of Medicine, Istanbul 34214, Turkey.
}

Correspondence to: Prof. Nevin Yilmaz, Gastroenterology/Hepatology Department, Near East University School of Medicine, Near East Boulevard, Nicosia, Mersın 10, Northern Cyprus. E-mail: nevinylmz@yahoo.com

How to cite this article: Yilmaz N, Yilmaz UE, Suer K, Goral V, Cakir N. Screening for hepatocellular carcinoma: summary of current guidelines up to 2018. Hepatoma Res 2018;4:46. http://dx.doi.org/10.20517/2394-5079.2018.49

Received: 2 May 2018 First Decision: 8 Jun 2018 Revised: 24 Jun 2018 Accepted: 29 Jun 2018 Published: 16 Aug 2018

Science Editor: Guang-Wen Cao Copy Editor: Jun-Yao Li Production Editor: Huan-Liang Wu

\begin{abstract}
Hepatocellular carcinoma (HCC) is one of the leading causes of cancer related to worldwide death with a great geographical variation. To be eligible for curative therapy at the time of diagnosis is important. However, the majority of cases are diagnosed at late stages. This can be achieved with applicable screening modalities. Until now, many organizations around the world have developed guidelines according to their own evidence-based data for screening of HCC. The purpose of this article is to review the screening modalities of HCC to assist gastroenterologists and providers involved in the management of HCC.
\end{abstract}

Keywords: Hepatocellular carcinoma, screening, guidelines, surveillance

\section{INTRODUCTION}

As emphasized in publications, liver cancer is the second most common cause of worldwide cancer deaths with the fifth most common cancer in men and the ninth in women in $2012^{[1]}$. Hepatocellular carcinoma (HCC) represents the major histological sub-type up to $90 \%$ of primary liver cancers ${ }^{[2-5]}$.

The first HCC cases in hepatitis-associated cirrhosis have been reported in the $19400^{\text {' }}{ }^{[6]}$. Following the dis-

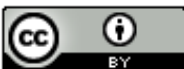

(C) The Author(s) 2018. Open Access This article is licensed under a Creative Commons Attribution 4.0 International License (https://creativecommons.org/licenses/by/4.0/), which permits unrestricted use, sharing, adaptation, distribution and reproduction in any medium or format, for any purpose, even commercially, as long as you give appropriate credit to the original author(s) and the source, provide a link to the Creative Commons license, and indicate if changes were made.

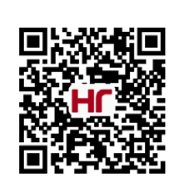


covery of alpha-fetoprotein (AFP) in HCC by the Russian scientist, screening HCC is widely recommended for patients who are under risk for more than 40 years $^{[7,8]}$.

Over the time, the underlying etiologies, incidence, and HCC outcomes are changed according to the countries. While the incidence of HCC is rising in the west, attributed to the past HCV epidemia (baby-boomers) and trends of metabolic disorders, it is decreasing in the East ${ }^{[9-11]}$. In despite of receiving regular HCC surveillance, nearly $40 \%$ of patients still died in 5 years $^{[12,13]}$. These changes are accommodating the new research on and development of new guidelines for HCC management.

Guidelines mean "rules or instructions about the best way to do something"[14]. They assist health care providers in the decision-making process according to evidence-based data, with guiding clinical practice in circumstances where all possible resources and therapies are available ${ }^{[15]}$. International scientific societies have issued recommendations for establishing a common standardized approach in the management of HCC.

Although these organizations are international, the recommendation-guidelines mostly directed to their own cases. It is essential for gastroenterologist to be familiar with these organizations and their proposed guidelines. As recommended in the guidelines, it is more appropriate to follow the guidelines but to adapt on the patient basis. In this article, you will find a summary of the current screening guidelines for HCC of three different continents.

\section{CURRENT GUIDELINES}

The success of the screening is influenced by the availability of effective treatment with the identification of the target population and the selection of appropriate screening tests. The cost-effectiveness should also be taken into consideration. In this review, the target group is divided into cirrhotic and non-cirrhotic patient group.

\section{Screening recommendations for cirrhotic adults}

Cirrhosis is the strongest predisposing factor for HCC formation. Nearly 85\%-95\% of HCC is developed on the cirrhotic liver ${ }^{[16-18]}$. These patients have a lifetime risk of developing HCC by $30 \%$ with leading cause of liver related death in compensated cirrhosis ${ }^{[2,19,20]}$. The risk varies with the underlying condition; the highest 5-year cumulative risks are reported in HCV cirrhosis (17\% in the west, $30 \%$ in Japan), hemochromatosis (21\%), HBV cirrhosis (10\% in high endemic areas, $15 \%$ in the west), alcoholic cirrhosis (8\%-12\%), and biliary cirrhosis (4\%). Also, the presence of co-infection (HCV/HBV or HBV/HCV) or alcohol abuse increases the risk by at least $200 \%{ }^{[21]}$. In addition to underlying etiology, other patient-related factors influence the risk of HCC. In general, low platelet count of less than $100 \times 10^{9} / \mathrm{L}$, presence of esophageal varices in addition to older age and male gender correlate with development of HCC among patients with cirrhosis ${ }^{[22-24]}$. However, current guidelines do not incorporate with the risk of stratification models (RSM) for cirrhotic that may be useful in the future for excluding some patients from screening.

Screening modalities consist of the periodic application of diagnostic tools with cost effectiveness which is generally taken into consideration based on the gain of life expectancy and guidelines indicating that an incidence of $\geq 1.5 \%$ year would warrant surveillance of HCC in cirrhosis ${ }^{[25,26]}$. Guidelines including the last updated screening section with data-supported recommendations were selected for the review; recommendations are as follows.

\section{From North America}

The American Association for the Study of Liver Diseases (AASLD-2017): routine screening is recommended for HCC in adults with cirrhosis. The initial screening is performed with ultrasound (US) with or without 
alpha- fetoprotein (AFP) every 6 months. AASLD does not suggest performing surveillance of patients with Child-Pugh class $\mathrm{C}$ cirrhosis unless they are on the transplant waiting list, given the low anticipated survival for these patients. They pointed out some technical remarks regarding screening modalities (US alone or plus AFP), interval (4-8 months) and modification in screening strategy based on etiology of liver diseases or risk stratification model ${ }^{[26]}$. In the previous guideline (AASLD-2011), ultrasound scanning alone was recommended $^{[27]}$.

The Canadian Association for the Study of the Liver (CASL 2014): this report is from consensus conference updated of the existing consensus - CASL 2011. The current statements for cirrhosis are similar with AASLD except they recommend US alone in every 6 months. The committee does not recommend AFP either alone or combined with US due to less sensitivity of AFP (67\% sensitivity). They also do not recommend other biomarkers (AFP) lectin fraction (AFP-L3) and des-gamma-carboxy prothrombin (DCP) due to less validation $^{[28,29]}$.

\section{From Asia}

The Asian Pacific Association for the Study of the Liver (APASL-2017): their recommendation is using combination of US and serum AFP measurement in every 6 months. The cut-off value of AFP should be set at $200 \mathrm{ng} / \mathrm{mL}$ for the cirrhotics. They do not suggest screening to cirrhotics not ineligible for treatments due to severe liver disease or other comorbidities which is similar with North America groups ${ }^{[30]}$.

CHINESE-2017: updated from 2011. Their recommendation for cirrhosis is identical with APASL. The only difference is that there is no excluding criteria for severe liver diseases ${ }^{[31]}$.

The Japan Society of Hepatology (JSH-2015): updated from 2013. Modalities and screening intervals mostly differ from the other countries and Asia. Besides AFP, a protein induced by vitamin K absence or antagonistII (PIVKA-II) and AFP-L3 measurements are also recommended by the JSH to increase sensitivity. The JSH evidence-based clinical practice guidelines for HCC divided patients into an extremely high-risk group (hepatitis B or C cirrhosis) and a high-risk group (patients with chronic hepatitis B, chronic hepatitis C, or non-viral cirrhosis). Their recommendations for extremely high-risk patients are periodic imaging screening by US every 3-4 months along with three tumour markers (AFP, PIVKA-II and AFP-L3). Additionally, they recommend multi-detector computed tomography (MDCT) or MRI examinations in every 6-12 months as the first step of screening (optional) method even there is no evidence of tumour on US, because of poor visualization capability ${ }^{[32,33]}$. The recommendations for the high-risk group cirrhosis are more cost effective and included periodic screening by US along with three tumour markers, every 6 months. MDCT and MRI are not recommended for high-risk patients ${ }^{[32,33]}$.

Japan Society of Hepatology- Liver Cancer Study Group (JSH-LCSG 2014): consensus-based guidelines. The JSH-LCSG practice guidelines use identical definitions for the extremely high-risk group and high-risk group. However, JSH-LCSG recommends EOB-MRI (gadolinium-ethoxybenzyl-diethylenetriamine pentaacetic acid-enhanced magnetic resonance imaging) instead of dynamic MDCT which has higher detection sensitivity than CT, as the first-line modality for surveillance every 6-12 months, even if no tumour is detected on $\mathrm{US}^{[33,34]}$.

\section{From Europe}

The European Association for the Study of the Liver (EASL-2018): the guideline is in press, their screening recommendations for Child-Pugh stage A and B patients are used by abdominal ultrasound every six months. AFP or other tumour biomarkers (AFP, AFP-L3 and DCP) are not recommended due to less accuracy for early detection of HCC. Stage C cirrhosis is excluded from screening except for transplant candidates $^{[2]}$. 
Table 1. Recommendations for cirrhotic adults

\begin{tabular}{|c|c|c|c|c|}
\hline Continent & Guidelines & Modality & $\begin{array}{l}\text { Time interval } \\
\text { (months) }\end{array}$ & Exceptions \\
\hline \multirow[t]{2}{*}{ North America } & AASLD-2017 & US with or without AFP & 6 & $\begin{array}{l}\text { Child-Pugh stage } C \text { unless awaiting } \\
\text { liver transplantation }\end{array}$ \\
\hline & CASL-2014 & US & 6 & Same as AASLD \\
\hline \multirow[t]{6}{*}{ Asia } & APASL-2017 & US and AFP & 6 & $\begin{array}{l}\text { Severe liver diseases/other co- } \\
\text { morbidities (ineligible for curative } \\
\text { therapy) }\end{array}$ \\
\hline & CHINESE-2017 & US and AFP & 6 & NS \\
\hline & JSH-2015* & $\begin{array}{l}\text { Extremely-high risk patients: (HBV/HCV } \\
\text { cirrhosis) } \\
\text { - US and three Tm markers (AFP/PIVKA-II/ } \\
\text { AFP-L3) }\end{array}$ & $3-4$ & \\
\hline & & - CT or MRI (optional) & $6-12$ & NS \\
\hline & & $\begin{array}{l}\text { High risk patients: (cirrhosis of another } \\
\text { etiology) } \\
\text { US and three tumor markers (AFP/PIVKA- } \\
\text { II, AFP-L3) }\end{array}$ & 6 & \\
\hline & JSH-LCSG-2014 & Recommend EOB-MRI instead of CT or MR & Same as JSH & NS \\
\hline \multirow[t]{4}{*}{ Europe } & EASL-2018** & US & 6 & Same as AASLD \\
\hline & $\begin{array}{l}\text { SPANISH-2016 (AEEH, } \\
\text { SEOM, SERAM, } \\
\text { SERVEI and SETH) }\end{array}$ & US & 6 & NS \\
\hline & SEOM-2015 & US & 6 & Same as AASLD \\
\hline & ESMO-ESDO-2012 & US & 6 & NS \\
\hline
\end{tabular}

*3rd JSH-HCC guidelines, 2013 update; ${ }^{\star *}$ in press. HBV: hepatitis B virus; HCV: hepatitis C virus; AFP: alpha-fetoprotein; NS: not specified; US: ultrasound; PIVKA-II: proteins induced by vitamin K absence; CT: computed tomography; MRI: magnetic resonance imaging; EOPMRI: gadolinium-ethoxybenzyl-diethylenetriamine pentaacetic acid (Gd-EOBDTPA)-enhanced magnetic resonance imaging

Selected guidelines from Spain (consensus document from The Spanish Association for the Study of the Liver (AEEH), Spanish Society of Medical Oncology (SEOM), The Spanish Society of Medical Radiology (SERAM), The Spanish Society of Vascular and International Radiology (SERVEI), The Spanish Society of Liver Transplantation (SETH)-2016 and European Society for Medical Oncology (ESMO)/European Society of Digestive Oncology (ESDO)-2012 recommend every 6 months US examination to patients with or without cirrhosis, and specify the theory behind this recommendation ${ }^{[35,36]}$. However; SEOM-2015 guideline excluded Child C patients from screening (unless awaiting for liver transplantation) like EASL ${ }^{[37]}$.

This section was summarized in Table 1.

\section{Recommendations for non-cirrhotic adults}

A small proportion of patients with HCC is diagnosed in the non-cirrhotic liver (NCL) with the risk of being less than $1 \%$ annually in patients with chronic hepatitis without significant fibrosis, in contrast to 3\%-7\% annually when the patient develops cirrhosis ${ }^{[26,35,38]}$. HCC in NCL ranges widely from $7 \%$ to $54 \%$ according to the etiology of the liver disease and varies of the geographic areas ${ }^{[39]}$. While viral hepatitis is pre-screened with decrease in the east as known, metabolic causes predominate in the west.

As compared to cirrhotic HCC, it has lower prevalence of the three main risk factors (hepatitis B and C virus infections and alcohol abuse), with an increased prevalence of other etiological factors, such as non-alcoholic fatty liver diseases, obesity and type 2 diabetes mellitus, exposure to genotoxic substances-aflatoxin, tobacco, sex hormones, inherited diseases and genetic mutations ${ }^{[2,3,11,26,30,36,38-40]}$.

In contrast to cirrhotic, NCL-HCC are more suitable for surgical treatments even in more advanced tumour stage at the time of diagnosis, since it is generally detected at a symptomatic stage due to unsettled scheduled screening program in these groups ${ }^{[2,38,39]}$. 
There is also a risk stratification model for non-cirrhotic HCCs. PAGE-B (platelet, age, gender, hepatitis B) that is developed for HBV is recommended for non-cirrhotic HBV patients by EASL-2018 ${ }^{[2,24,41]}$.

Recommendations from guidelines are as follows.

From North America

AASLD-2017: there is no proposal for non-cirrhotic patients in the current guideline. The previous AASLD guideline (2010), described the high-risk HBV carriers for HCC [Table 2] and the recommendation for screening was US in every 6 months ${ }^{[26,27]}$.

CASL-2014: identical with AASLD-2010, the CASL recommends HCC screening for the following high-risk groups by using US in every 6 months: Asian male hepatitis B carriers over the age of 40, Asian female hepatitis B carriers over the age of 50, hepatitis B carriers with a family history of HCC, Africans and African Americans with hepatitis $\mathrm{B}^{[29]}$.

From Asia

APASL-2017: recommendations for non-cirrhotic group similar to CASL. Differently, they recommend screening in Africans older than 20 years old. The surveillance strategy is combination of US and serum AFP, every 6 months, recommending that the cut-off value of AFP can be set at a lower value in a population with hepatitis virus suppression or eradication ${ }^{[30]}$.

CHINESE-2017: recommendations for non-cirrhotic-chronic liver diseases (any etiology) are AFP with ultrasonography in every 6 months for surveillance ${ }^{[31]}$.

JSH-2015 and JSH-LCSG 2014: for the high- risk non-cirrhotic (patients with chronic hepatitis B, chronic hepatitis C), they recommend an US examination along with measurement of three tumour markers (AFP/ PIVKA-II, AFP-L3) in every 6 months [Table 2 $]^{[32-34]}$.

\section{From Europe}

EASL-2018: categorized the non-cirrhotic HBV patients at intermediate or high risk of HCC according to PAGE-B classes for Caucasian subjects, respectively 10-17 and $\geq 18$ score points $^{[2,41]}$.

To this group and non-cirrhotic F3 patients, regardless of etiology screening based on an individual, risk assessment is recommended for patients in the low HCC risk class (PAGE-B score $\leq 9$ ), who do not reach the $0.2 \% /$ year threshold for starting screening. The PAGE-B score has not yet been validated in Asia due to Caucasian subjects. They recommend an US examination in every 6 months ${ }^{[2]}$.

The consensus document from the AEEH, SEOM, SERAM, SERVEI and SETH -2016 has not specified the screening for non-cirrhotic subjects ${ }^{[35]}$. However, SEOM-2015 recommended screening for high-risk HBV chronic hepatitis patients (higher viral load, viral genotype or Asian or African ancestry) and non-cirrhotic patients with chronic hepatitis $\mathrm{C}$ and advanced fibrosis $(\mathrm{F} 3)^{[37]}$.

ESMO-ESDO-2012 recommendations are similar to SEOM-2015, which suggests to non-cirrhotic HBV carriers with high viral load (> 10.000 copy $/ \mathrm{mL}$ ) and non-cirrhotic patients with chronic hepatitis $\mathrm{C}$ and advanced cirrhosis ${ }^{[36]}$.

This section was summarized in Table 2. 
Table 2. Recommendations for non-cirrhotic adults

\begin{tabular}{|c|c|c|c|c|}
\hline Continent & Guidelines & Target population & Modality & $\begin{array}{l}\text { Time interval } \\
\text { (months) }\end{array}$ \\
\hline \multirow[t]{3}{*}{ North America } & AASLD-2017 & \multicolumn{3}{|l|}{ No recommendation for surveillance of non-cirrhotics at this time } \\
\hline & AASLD-2010 & $\begin{array}{l}\text { HBV carriers: } \\
\text { - Asian female }>50 \text { years } \\
\text { - Asian male }>40 \text { years } \\
\text { - Family history of HCC } \\
\text { - African/North American Blacks }\end{array}$ & US & 6 \\
\hline & CASL-2014 & Same as AASLD-2010 & US & 6 \\
\hline \multirow[t]{3}{*}{ Asia } & APASL-2017 & $\begin{array}{l}\text { Non-cirrhotic (HBsAg positive): } \\
\text { - Asian females }>50 \text { years } \\
\text { - Asian males }>40 \text { years } \\
\text { - Africans aged }>20 \text { years } \\
\text { - History of HCC in the family }\end{array}$ & US and AFP & 6 \\
\hline & CHINESE-2017 & Chronic liver diseases of any etiology & US and AFP & 6 \\
\hline & $\begin{array}{l}\text { JSH-2015 and JSH- } \\
\text { LCSG-2014 }\end{array}$ & High risk patients (chronic hepatitis B or C) & $\begin{array}{l}\text { US and three tumor } \\
\text { markers AFP/PIVKA- } \\
\text { II/AFP-L3 }\end{array}$ & 6 \\
\hline \multirow[t]{4}{*}{ Europe } & EASL-2018 & $\begin{array}{l}\text { Non-cirrhotic HBV patients at intermediate or high risk of } \\
\text { HCC }^{\star} \\
\text { Non-cirrhotic F3 patients regardless of etiology }{ }^{\star \star}\end{array}$ & US & 6 \\
\hline & $\begin{array}{l}\text { SPANISH-2016 (AEEH, } \\
\text { SEOM, SERAM, SERVEI } \\
\text { and SETH) }\end{array}$ & \multicolumn{2}{|l|}{ No recommendation for surveillance of non-cirrhotics at this time } & \\
\hline & SEOM-2015 & $\begin{array}{l}\text { High-risk HBV chronic hepatitis patients (higher viral load, } \\
\text { viral genotype or Asian or African ancestry) } \\
\text { Non-cirrhotic patients with chronic hepatitis C and } \\
\text { advanced fibrosis (F3) }\end{array}$ & US & 6 \\
\hline & ESMO-ESDO-2012 & $\begin{array}{l}\text { Non-cirrhotic HBV carriers with high viral load (> 10,000 } \\
\text { copy/mL) } \\
\text { Non-cirrhotic patients with chronic hepatitis C and } \\
\text { advanced fibrosis (F3) }\end{array}$ & US & 6 \\
\hline
\end{tabular}

${ }^{\star}$ According to PAGE-B classes for Caucasian subjects, intermediate or high risk of HCC (10-17 and U 18 score points, respectively; ${ }^{\star \star}$ considered for surveillance based on an individual risk assessment. HCC: hepatocellular carcinoma; F3: bridging fibrosis; HBV: hepatitis $B$ virus; AFP: alpha-fetoprotein; US: ultrasound

\section{REMARKS FROM GUIDELINES \& COMMENTS}

All three continents propose a 6-month screening interval using ultrasonography with or without AFP, regardless of cirrhosis, except Japan. Japanese guidelines suggest a shorter interval (3-4 months) for extremely high-risk cirrhotic patients, the three tumour markers (AFP/PIVKA-II, /AFP-L3) along with ultrasound and EOB-MRI with 6-12 months interval, or dynamic CT.

Based on the tumour doubling time (range 29 to 398 days), the 6-month interval represents a reasonable choice $^{[42]}$, since shorter interval detects more small lesions, but does not improve detection of small HCC $^{[43]}$. The incidence of HCC in the target population and available facilities may affect the screening interval. However, there is still a question about optimal interval for screening ranging from 4 to 8 months ${ }^{[2,26,30]}$.

Sensitivity of ultra-sonogram is ranging from $58 \%$ to $89 \%$ with specificity greater than $90 \%$ when used as a screening test before they presented clinically, other than that it seems to be less effective for detecting earlystage HCC (sensitivity of only $63 \%)^{[2,26,44,45]}$.

AFP is not recommended along with ultrasound in North America and Europe because the present studies were not directed to determine an improvement in survival. AFP is usually elevated in cirrhosis intermittently, but markedly elevation in small tumour is rare ${ }^{[2,16,26,30]}$. Therefore, APASL suggests cut-off value (set at $200 \mathrm{ng} / \mathrm{mL}$ ) of AFP for screening programs when used in combination with US. Combined with US, AFP provides additional detection in $6 \%-8 \%$ of cases not previously identified by US, confirmed more recently ${ }^{[2,46]}$.

Serological tests that are under investigation for early diagnosis of HCC include (PIVKA II) AFP-L3, alphafucosidase, and glypican. These markers have been tested mostly for diagnosis and prognosis, but need to be 
studied in screening set-up ${ }^{[2,26,30]}$.

As imaging modality, Japanese guidelines recommend EOB-MRI or dynamic CT to be performed in every 6-12 months for screening for extremely high-risk of cirrhotic patients since small nodules may not be detected on ultrasound alone ${ }^{[32,34]}$.

HCC risk stratification models for cirrhotics have not yet been included in the guidelines and the majority of the presented guidelines exclude Child C cirrhosis from screening protocols unless they are eligible for curative therapy.

Screening guidelines for non-cirhotics differ from countries, mainly in selection of the target population. Whereas AASLD-2017 does not specify, APASL-2017 and EASL-2018 describe the target population in the guidelines.

EASL-2018 made a breakthrough and used the PAGE B score system for non-cirrhotic HBV patients. The score system is intended to determine unnecessary screening for Caucasian patients with chronic HBV. However, the PAGE-B score has not yet been validated in Asia ${ }^{[2]}$.

Overall F3 (bridging fibrosis) patients regardless of aetiology were also included in the screening protocol at first time by EASL-2018 developers.

CHINESE-2017 recommends screening for patients with chronic liver diseases regardless of aetiology. In contrast, Japan guidelines suggest screening for patients with only chronic HBV and HCV.

In general, the screening modalities for non-cirhotics are almost identical with cirrhotics except Japan guidelines. The Japan guidelines recommend the three tumour markers additional to ultra-sonogram, for every 6 months.

Final question is: do the screening modalities really work? Japan and Hong Kong HCC screening methods were compared in that particular context. In Hong Kong, where there was no formal surveillance program, $20 \%$ of HCC were detected only in the pre-symptomatic period with low survival rate (17.8 months) whereas in Japan over $75 \%$ of cases were detected by surveillance. The median survival was 52 months in Japan and the stage of HCC at presentation was the most important factor influencing survival according to the cohort $^{[47]}$.

\section{CONCLUSION}

Recommendations from the three continents are mostly influenced in the prevalence of HCC and availability of resources. It may be necessary to modify the screening methods according to the condition of patients. This situation is more evident in those countries with no national guidelines and/or heterogeneous patient population. Hence, developing countries should be encouraged to issue their own guidelines. The common point is that, cost-effectiveness is universal and screening modality is one of the factors that influence the variation in survival.

\section{DECLARATIONS}

\section{Acknowledgments}

Special thanks to Burhan Gurtunca, $\mathrm{PhD}$ for his contributions on editing. 


\section{Authors' contributions}

Design: Yilmaz N

Literature review: Yilmaz N, Suer K, Goral V, Cakir N

Manuscript writing: Yilmaz N

Manuscript review and editing: Yilmaz UE

Approved the final article: all authors

\section{Availability of data and materials}

Not applicable.

\section{Financial support and sponsorship}

None.

\section{Conflicts of interest}

All authors declared that there are no conflicts of interest.

\section{Ethical approval and consent to participate}

Not applicable.

\section{Consent for publication}

Not applicable.

\section{Copyright}

(c) The Author(s) 2018.

\section{REFERENCES}

1. International Agency for Research on Cancer. GLOBOCAN 2012: Estimated Cancer Incidence, Mortality and Prevalence Worldwide in 2012. Available from: http://globocan.iarc.fr/Pages/fact_sheets_cancer.aspx. [Last accessed on 10 Aug 2018]

2. European Association for the Study of the Liver. EASL Clinical Practice Guidelines: management of hepatocellular carcinoma. J Hepatol 2018;69:182-236.

3. El-Serag H, Kanwal H. Epidemiology of hepatocellular carcinoma in the United States: where are we? where do we go? Hepatology 2014;60:1767-75.

4. Torre LA, Siegel RL, Ward EM, Jem A. Global cancer incidence and mortality rates and trends--an update. Cancer Epidemiol Biomarkers Prev 2016;25:16-27.

5. Altekruse SF, McGlynn KA, Reichman MA. Hepatocellular carcinoma incidence, mortality, and survival trends in the United States from 1975 to 2005. J Clin Oncol 2009;27:1485-91.

6. Sheldon WH, James DF. Cirrhosis following infectious hepatitis; a report of five cases, in two of which there was superimposed primary liver cell carcinoma. Arch Intern Med (Chic) 1948;81:666-89.

7. Nikulina D, Terentyev A, Galimzyanov K, Jurišić V. Fifty years of discovery of alpha-fetoprotein as the first tumor marker. Srp Arh Celok Lek 2015;143:100-4.

8. Tang ZY. Screening and early treatment of primary liver cancer--with special reference to the east part of China. Ann Acad Med 1980;9:2349.

9. Altekruse SF, Henley SJ, Cucinelli JE, Mc Glynn KA. Changing hepatocellular carcinoma incidence and liver cancer mortality rates in the United States. Am J Gastroenterol 2014;109:542-53.

10. Jemal A, Bray B, Center MM, Ferlay F, Ward E, Forman D. Global cancer statistics. CA Cancer J Clin 2011;61:69-90.

11. Global Burden of Disease Liver Cancer Collaboration; Akinyemiju T, Abera S, Ahmed M, Alam N, Alemayohu MA, Allen C, Al-Raddadi R, Alvis-Guzman N, Amoako Y, Artaman A, Ayele TA, Barac A, Bensenor I, Berhane A, Bhutta Z, Castillo-Rivas J, Chitheer A, Choi JY, Cowie B, Dandona L, Dandona R, Dey S, Dicker D, Phuc H, Ekwueme DU, Zaki MS, Fischer F, Fürst T, Hancock J, Hay SI, Hotez P, Jee SH, Kasaeian A, Khader Y, Khang YH, Kumar A, Kutz M, Larson H, Lopez A, Lunevicius R, Malekzadeh R, McAlinden C, Meier T, Mendoza W, Mokdad A, Moradi-Lakeh M, Nagel G, Nguyen Q, Nguyen G, Ogbo F, Patton G, Pereira DM, Pourmalek F, Qorbani M, Radfar A, Roshandel G, Salomon JA, Sanabria J, Sartorius B, Satpathy M, Sawhney M, Sepanlou S, Shackelford K, Shore H, Sun J, Mengistu DT, Topór-Mądry R, Tran B, Ukwaja, Vlassov V, Vollset SE, Vos T, Wakayo T, Weiderpass E, Werdecker A, Yonemoto N, Younis M, Yu C, Zaidi Z, Zhu L, Murray CJL, Naghavi M, Fitzmaurice C. The burden of primary liver cancer and underlying etiologies from 1990 to 2015 at the global, regional, and national level. JAMA Oncol 2017;3:1683-91.

12. Wong GL, Wong VW, Tan GM, Ip KI, Lai WK, Li YW, Mak MS, Lai PB, Sung JJ, Chan HL. Surveillance programme for hepatocellular carcinoma improves the survival of patients with chronic viral hepatitis. Liver Int 2008;28:79-87.

13. Wong GL. Optimal surveillance program for hepatocellular carcinoma - getting ready, but not yet. World J Hepatol 2015;7:2133-5. 
14. Guideline. Available from: https://www.ldoceonline.com/dictionary/guideline. [Last accessed on 10 Aug 2018]

15. European Association For The Study Of The Liver; European Organisation For Research And Treatment Of Cancer. EASL-EORTC clinical practice guidelines: management of hepatocellular carcinoma. J Hepatol 2012;56:908-43.

16. Llovet JM, Burroughs A, Bruix A. Hepatocellular carcinoma. Lancet 2003;362:1907-17.

17. El-Serag HB, Rudolph KL. Hepatocellular carcinoma: epidemiology and molecular carcinogenesis. Gastroenterology 2007;132:2557-76.

18. Forner A, Reig M, Bruix J. Hepatocellular carcinoma. Lancet 2018;391:1301-14.

19. Sangiovanni A, Prati GM, Fasani P, Ronchi G, Romeo R, Manini M, Del Ninno E, Morabito A, Colombo M. The natural history of compensated cirrhosis due to hepatitis C virus: a 17-year cohort study of 214 patients. Hepatology 2006;43:1303-10.

20. Hung TH, Liang CM, Hsu CN, Tai WC, Tsai KL, Ku MK, Wang JW, Tseng KL, Yuan LT, Nguang SH, Yang SC, Wu CK, Hsu PI, Wu DC, Chuah SK. Association between complicated liver cirrhosis and the risk of hepatocellular carcinoma in Taiwan. PLoS One 2017;12:e181858.

21. Fattovich G, Stroffolini T, Zagni I, Donato F. Hepatocellular carcinoma in cirrhosis: incidence and risk factors. Gastroenterology 2004;127:S35-50.

22. Flemming JA, Yang JD, Vittinghoff E, Kim WR, Terrault NA. Risk prediction of hepatocellular carcinoma in patients with cirrhosis: the ADRESS-HCC risk model. Cancer 2014;120:3485-93.

23. Lok AS, Seeff LB, Morgan TR, di Bisceglie AM, Sterling RK, Curto TM, Everson GT, Lindsay KL, Lee WM, Bonkovsky HL, Dienstag JL, Ghany MG, Morishima C, Goodman ZD; HALT-C Trial Group. Incidence of hepatocellular carcinoma and associated risk factors in hepatitis C-related advanced liver disease. Gastroenterology 2009;136:138-48.

24. Fateen W, Ryder SD. Screening for hepatocellular carcinoma: patient selection and perspectives. J Hepatocell Carcinoma 2017;4:71-9.

25. Sarasin FP, Giostra E, Hadengue A. Cost-effectiveness of screening for detection of small hepatocellular carcinoma in western patients with Child-Pugh class A cirrhosis. Am J Med 1996;101:422-34.

26. Heimbach JK, Kulik LM, Finn RS, Sirlin CB, Abecassis MM, Roberts LR, Zhu AX, Murad MH, Marrero JA. AASLD guidelines for the treatment of hepatocellular carcinoma. Hepatology 2018;67:358-80.

27. Bruix J, Sherman M. Management of hepatocellular carcinoma: an update. Hepatology 2011;53:1020-2.

28. Sherman M, Burak K, Maroun J, Metrakos P, Knox JJ, Myers RP, Guindi M, Porter G, Kachura JR, Rasuli P, Gill S, Ghali P, Chaudhury P, Siddiqui J, Valenti D, Weiss A, Wong R. Multidisciplinary Canadian consensus recommendations for the management and treatment of hepatocellular carcinoma. Curr Oncol 2011;18:228-40.

29. Burak KW, Sherman M. Hepatocellular carcinoma: consensus, controversies and future directions: a report from the Canadian Association for the Study of the Liver Hepatocellular Carcinoma Meeting. Can J Gastroenterol Hepatol 2015;29:178-84.

30. Omata M, Cheng AL, Kokudo N, Kudo M, Lee JM, Jia J, Tateishi R, Han KH, Chawla YK, Shiina S, Jafri W, Payawal DA, Ohki T, Ogasawara S, Chen PJ, Lesmana CRA, Lesmana LA, Gani RA, Obi S, Dokmeci AK, Sarin SK. Asia-Pacific clinical practice guidelines on the management of hepatocellular carcinoma: a 2017 update. Hepatol Int 2017;11:317-70.

31. Xie DY, Ren ZG, Zhou J, Fan J, Gao Q. Critical appraisal of Chinese 2017 guideline on the management of hepatocellular carcinoma. Hepatobiliary Surg Nutr 2017;6:387-96.

32. Kokudo N, Hasegawa K, Akahane M, Igaki H, Izumi N, Ichida T, Uemoto S, Kaneko S, Kawasaki S, Ku Y, Kudo M, Kubo S, Takayama T, Tateishi R, Fukuda T, Matsui O, Matsuyama Y, Murakami T, Arii S, Okazaki M, Makuuchi M. Evidence-based clinical practice guidelines for hepatocellular carcinoma: the Japan Society of Hepatology 2013 update (3rd JSH-HCC Guidelines). Hepatol Res 2015;45:12464.

33. Kudo M. Clinical practice guidelines for hepatocellular carcinoma differ between Japan, United States, and Europe. Liver Cancer 2015;4:85-95.

34. Kudo M, Matsui O, Izumi N, Iijima H. JSH consensus-based clinical practice guidelines for the management of hepatocellular carcinoma: 2014 update by the Liver Cancer Study Group of Japan. Liver Cancer 2014;3:458-68.

35. Forner A, Reig M, Varela M, Burrel M, Feliu J, Briceño J, Sastre J, Martí-Bonmati L, Llovet JM, Bilbao JI, Sangro B, Pardo F, Ayuso C, Bru C, Tabernero J, Bruix J. Diagnosis and treatment of hepatocellular carcinoma. Update consensus document from the AEEH, SEOM, SERAM, SERVEI and SETH. Med Clin 2016;146:511.e1-22.

36. Verslype C, Rosmorduc O, Rougier P. Hepatocellular carcinoma: ESMO-ESDO clinical practice guidelines. Ann Oncol 2012;23:41-8.

37. Sastre J, Díaz-Beveridge R, García-Foncillas J, Guardeño R, López C, Pazo R, Rodriguez-Salas N, Salgado M, Salud A, Feliu J. Clinical guideline SEOM: hepatocellular carcinoma. Clin Transl Oncol 2015;17:988-95.

38. Schütte K, Schulz C, Poranzke J, Antweiler K, Bornschein J, Bretschneider T, Arend J, Ricke J, Malfertheiner P. Characterization and prognosis of patients with hepatocellular carcinoma (HCC) in the non-cirrhotic liver. BMC Gastroenterol 2014;14:117.

39. Trevisani F, Frigerio M, Santi V, Grignaschi A, Bernardi M. Hepatocellular carcinoma in non-cirrhotic liver: a reappraisal. Dig Liver Dis 2010;42:341-7.

40. Lee YC, Cohet C, Yang YC, Stayner L, Hashibe M, Straif K. Meta-analysis of epidemiologic studies on cigarette smoking and liver cancer. Int J Epidemiol 2009;38:1497-511.

41. Papatheodoridis G, Dalekos G, Sypsa V, Yurdaydin C, Buti M, Goulis J, Calleja JL, Chi H, Manolakopoulos S, Mangia G, Gatselis N, Keskin O, Savvidou S, de la Revilla J, Hansen BE, Vlachogiannakos I, Galanis K, Idilman R, Colombo M, Esteban R, Janssen HL, Lampertico P. PAGE-B predicts the risk of developing hepatocellular carcinoma in Caucasians with chronic hepatitis B on 5-year antiviral therapy. J Hepatol 2016;64:800-6.

42. Sheu JC, Sung JL, Chen DS, Yang PM, Lai MY, Lee CS, Hsu HC, Chuang CN, Yang PC, Wang TH, Lin JT, Lee CZ. Growth rate of asymptomatic hepatocellular carcinoma and its clinical implications. Gastroenterology 1985;89:259-66.

43. Trinchet JC, Chaffaut C, Bourcier V, Degos F, Henrion J, Fontaine H, Roulot D, Mallat A, Hillaire S, Cales P, Ollivier I, Vinel JP, Mathurin P, Bronowicki JP, Vilgrain V, N'Kontchou G, Beaugrand M, Chevret S; Groupe d'Etude et de Traitement du Carcinome Hépatocellulaire (GRETCH). Ultrasonographic surveillance of hepatocellular carcinoma in cirrhosis:a randomized trial comparing 3- and 6-month periodicities. Hepatology 2011;54:1987-97. 
44. Bolondi L. Screening for hepatocellular carcinoma in cirrhosis. J Hepatol 2003;39:1076-84.

45. Singal A, Volk ML, Waljee A, Salgia R, Higgins P, Rogers MA, Marrero JA. Meta-analysis: surveillance with ultrasound for early-stage hepatocellular carcinoma in patients with cirrhosis. Aliment Pharmacol Ther 2009;30:37-47.

46. Biselli M, Conti F, Gramenzi A, Frigerio M, Cucchetti A, Fatti G, D’Angelo M, Dall'Agata M, Giannini EG, Farinati F, Ciccarese F, Andreone $\mathrm{P}$, Bernardi M, Trevisani F. A new approach to the use of $\alpha$-fetoprotein as surveillance test for hepatocellular carcinoma in patients with cirrhosis. Br J Cancer 2015;112:69-76.

47. Johnson P, Berhane S, Kagebayashi C, Satomura S, Teng M, Fox R, Yeo W, Mo F, Lai P, Chan SL, Tada T, Toyoda H, Kumada T. Impact of disease stage and aetiology on survival in hepatocellular carcinoma: implications for surveillance. Br J Cancer 2017;116:441-7. 